Article

\title{
An Investigation of Passengers' Psychological Benefits from Green Brands in an Environmentally Friendly Airline Context: The Moderating Role of Gender
}

\author{
Jinsoo Hwang ${ }^{1}$ and Jung Kyu Choi ${ }^{2, *}$ \\ 1 The College of Hospitality and Tourism Management, Sejong University, 98 Gunja-Dong, Gwanjin-Gu, \\ Seoul 143-747, Korea; jhwang@sejong.ac.kr \\ 2 Department of International Logistics, Dongseo University, 47 Jurye-ro, Sasang-gu, Busan 617-716, Korea \\ * Correspondence: jkchoi@dongseo.ac.kr
}

Received: 31 October 2017; Accepted: 21 December 2017; Published: 30 December 2017

\begin{abstract}
In recent years, as natural environmental problems have become more serious, environmentally friendly airlines have been attracting attention from many practitioners and scholars. The purpose of this study was to apply the concept of psychological benefits of green brands in an environmentally friendly airline context. Based on the theoretical relationships between the conceptual constructs, a model was developed and then evaluated using data collected from 322 airline passengers in Korea. The results indicated that the three sub-dimensions of psychological benefits of green brands (i.e. warm glow, self-expressive benefits and nature experiences) help to enhance the overall image of an environmentally friendly airline. Furthermore, the overall image plays an important role in the formation of three outcome variables: intentions to use, word-of-mouth intentions and willingness to pay more. Lastly, gender moderates the relationship between overall image and intentions to use.
\end{abstract}

Keywords: environmentally friendly airline; psychological benefits; warm glow; self-expressive benefits; nature experiences; overall image; gender

\section{Introduction}

Recently, serious environmental issues have witnessed a surge in interest because global warming and environmental contamination threatens not only human but also ecosystem survival, resulting in people increasingly working very hard to protect the environment and nature $[1,2]$. We can find this change manifesting itself in consumer behavior, with consumers tending to buy and use more environmentally friendly products/services in order to protect the Earth's environment [3-5]. For this reason, environmental management is receiving much attention from scholars and practitioners. In fact, many businesses have done a lot of work to respond to customers' environmental needs by developing and delivering more environmentally friendly products/services [6,7]. In product development, many companies consider the impact their products on the natural environment and also engage in green marketing activities for sustained consumption [8,9]. Environmental management is also important in the airline industry as many airlines have tried to create an image of being an environmentally friendly airline. For example, Asiana Airlines, one of the biggest airlines in Korea, engaged in the following environmentally-friendly activities [10]: (1) tree planting activities on the world's largest landfill; (2) installation of environmentally-friendly solar-powered streetlights; and (3) making efforts to reduce the use of fuel in every stage of aircraft operation. As a result, Asiana Airlines was chosen as the best airline 
company by the DJSI (Dow Jones Sustainability Index) for six consecutive years. Such environmental management helps to promote an image of an environmentally friendly airline [11,12].

More importantly, environmental management significantly aids in the provision of psychological benefits of green brands to their customers [13-15]. Psychological benefits refer to "feelings of trust or confidence in the other party that result in greater peace of mind" [16]. As customers perceive psychological benefits from the service provider, they are less likely to suffer from anxiety and are more likely to be comfortable and at ease [17]. In particular, psychological benefits of green brands lead to the creation of a positive overall image of the brand [15]. In other words, airlines can provide psychological benefits of green brands through environmental management which helps to form a favorable image. In addition, although it is well known that males and females behave differently [18,19], no previous study has examined gender differences in an environmentally friendly airline context.

Despite the importance of psychological benefits of green brands in the airline industry, to date no wide-ranging study has examined its role in the airline industry. Therefore, to fill this gap, the objective of this study was to investigate the importance of psychological benefits of green brands in the airline industry. More specifically, this study tries to examine (1) the effects of three sub-dimensions of psychological benefits of green brands including warm glow, self-expressive benefits and nature experiences on overall image; (2) the influences of overall image on its outcome variables such as intentions to use, word-of-mouth intentions, willingness to pay more; and (3) the moderating role of gender in the relationship between overall image and its outcome variables. It is very important to identify the psychological benefits of green brands in improving the overall image to keep current airline passengers and attract potential airline passengers, so the results of this study would be significant and meaningful to airline managers.

\section{Literature Review}

\subsection{Psychological Benefits of Green Brands}

Previous studies have consistently suggested that psychological benefits of green brands consisted of the following three sub-dimensions: (1) warm glow; (2) self-expressive benefits; and (3) nature experiences [20-22]. For instance, Hartmann and Apaolaza-Ibáñez [11] tested the uni-dimensionality of the three sub-dimensions using 432 samples and showed that there is no problem with convergent validity, discriminant validity, or internal consistency in the three sub-dimensions of psychological benefits of green brands. More recently, Lin et al. [23] collected data from 818 customers who had purchase experience of green brands in order to test the uni-dimensionality of the three sub-dimensions. The results indicated that convergent validity, discriminant validity and internal consistency were statistically supported. According to empirical backgrounds, this study adapted the three sub-dimensions of psychological benefits of green brands.

\subsubsection{Warm Glow}

The term warm glow can be defined as "satisfaction that goes beyond the benefits derived from aggregate provision of a public good through pro-environmental behavior" [24] (p. 239). That is, it is a direct, private benefit arising from the moral satisfaction of contributing to the common good for the environment [25-27]. People are willing to pay more money to purchase environmentally friendly products/services which help form self-satisfaction [28] because warm glow is caused by the pursuit of a positive emotional state to help others voluntarily $[29,30]$, so it is also known as intrinsic satisfaction [31]. In the same vein, as people contribute to the common good through environmental protection, they are more likely to achieve a high level of life satisfaction and happiness [25,32]. The level of warm glow is different depending on whether the person has a social responsibility [33]. In other words, if people have greater social responsibility, they would perceive a higher level of warm glow. On the contrary, if people feel that social responsibility is not important, they are less likely to feel a warm glow. 
Empirical studies also showed the importance of warm glow in consumer research. Hartmann and Apaolaza-Ibáñez [15] examined the relationship between warm glow and purchase intention using data collected from 726 consumers who were exposed to experimental green advertisements. They found that warm glow is a critical predictor of purchase intention. That is, when consumers have the feeling of contributing to the well-being of humanity and nature through the use of a green brand, they are more likely to purchase the green brand. In addition, Habel et al. [34] showed that if customers perceive warm glow when purchasing products, they are more likely to experience a higher perception of prices fairness.

\subsubsection{Self-Expressive Benefits}

Many practitioners as well as scholars have much interest in self-expressive benefits because it has a major influence on green consumer behavior [14,15]. The concept of self-expressive benefits is theoretically supported by the following two theories: signaling theory and self-congruity theory. First, signaling is the process of expressing personality characteristics such as preference or dislike of other people [35-37]. That is, consumers tend to convey information about their tendency towards the protection of the environment via the consumption of environmentally friendly products/services which leads to a higher level of self-expressive benefits [38]. Hartmann and Apaolaza-lbáñez [20] also argued that people try to purchase environmentally friendly products/services in order to show their pro-environmental attitudes. Second, according to self-congruity theory, consumers want to buy brands that match their image [39], suggesting that the higher the level of congruence, the higher the purchase intention [40]. From this point of view, the socially visible consumption of environmentally friendly products is the key factor affecting self-expressive benefits [41]. That is, consumers are more likely to perceive self-expressive benefits when environmentally friendly products/services can reflect well on their pro-social behaviors [42].

Previous research also suggested the important role of self-expressive benefits in the formation of managerial outcomes. For instance, Aaker [43] argued that if a brand provides self-expressive benefits, the relationship between the customer and the brand become stronger. In addition, Ahmad and Thyagaraj [44] explored the relationship between self-expressive benefits and purchase intention using data collected from 270 Indian respondents who had purchase experience of products made by a green electronics company. The results of their data analysis showed that self-expressive benefits have a positive influence on purchase intention.

\subsubsection{Nature Experiences}

People want to be with nature in order to recover their physical and mental health $[45,46]$ because natural experiences aid in enhancing emotional well-being and a positive mood $[47,48]$ and also decrease mental fatigue and the tendency for aggressive behavior [48,49]. For this reason, green brands try to use beautiful natural scenery in their advertising campaigns in order to promote feelings of restfulness and congeniality [15,50]. More importantly, nature experiences are considered the basis for environmental awareness which leads to pro-environmental consumer behavior $[13,15]$. That is, nature experiences are an important factor that drives eco-friendly behavior [51]. Bögeholz [50] also suggested that people who have a higher level of nature experiences tend to develop an awareness of protecting nature, so they are more likely to display environmentally friendly behaviors.

The importance of nature experiences was also investigated in diverse industries. For example, Mayer et al. [52] suggested that nature experiences play an important role in the formation of environmental values and attitudes, which in turn positively affect pro-environmental behavior. In addition, Andereck and Nyaupane [53] investigated the importance of nature experiences in tourism. They suggested that nature experiences play a role in the formation of quality of life. It can be interpreted that if tourists spend a lot of time in a natural environment during the trip, they are more likely to feel that their quality of life is enhanced. 


\subsection{Overall Image}

Over the past few decades, the concept of overall image has been studied in both academia and industry [54-57]. Numerous different definitions of overall image are available. For instance, some destination researchers defined overall image as the sum of individual beliefs, thoughts and impressions that are created by a certain place [54,58]. Bloemer and De Ruyter [56] defined overall image as a consumer's perceptions of a firm on different attributes. In addition, Han, Hsu and Lee [18] conceptualized overall image as customers' overall perceptions of a firm, formed by processing information and by prior or vicarious knowledge about a firm and its attributes. Although there is no consensus on the definition of overall image, they have commonly stressed the overall perceptions of an object or place. Thus, this study defined overall image as customers' overall perceptions formed by an environmentally friendly airline and its attributes.

\subsection{Intentions to Use}

Intentions to use can be defined as a stated likelihood to engage in a behavior in the future [59]. Intentions to use a particular product/service are formed after a positive assessment of the product/service, so intentions to use are connected directly to actual consumption $[60,61]$. For this reason, many studies have used the concept of intentions to use as main dependent variable in their proposed model $[57,62,63]$.

\subsection{Word-of-Mouth Intentions}

Word-of-mouth refers to "informal communication directed at other consumers about the ownership, usage, or characteristics of particular goods and services and/or their sellers" [64]. It is widely known that word-of-mouth has a greater influence on consumer decision making than commercial advertisements because consumers are more likely to have increased confidence in people around them [65]. From a company's point of view, since their products/services are promoted by consumers' voluntary and discretionary behaviors, word-of-mouth helps a company a lot in reducing the cost and time of marketing their products $[66,67]$.

\subsection{Willingness to Pay More}

Willingness to pay more is defined as the maximum amount of money customers are willing to spend for their preferred brand product over other comparable brands $[68,69]$. Customers tend to pay more for a high level of product quality which maximizes consumption values $[70,71]$. That is, when customers have a higher perceived value in relation to the cost of the product, they are willing to pay a relatively expensive price [72]. In addition, willingness to pay more has a major effect on the enhancement of sales and revenues, so it has been studied in diverse fields $[5,73,74]$.

\subsection{Hypotheses Development}

\subsubsection{The Effect of Warm Glow on Overall Image}

This study develops hypothesis 1 based on the following inferences. According to the warm glow theory, customers have a passion for the common good such as environmental protection which makes them feel good about themselves [28,29]. More importantly, warm glow is highly correlated with a brand image because consumers are more likely to have good feeling towards a certain brand if they have been highly satisfied with themselves by purchasing products of the brand that help protect the environment [15]. Therefore, it can be inferred that if passengers feel good because they help to protect the environment with an environmentally friendly airline, they are more likely to perceive a positive overall image when taking an environmentally friendly airline. Empirical studies also support this theoretical argument. For instance, Hartmann and Apaolaza-Ibáñez [13] found that warm glow helps to develop a good feeling toward green energy brands. In addition, Müller, Fries and Gedenk [75] 
suggested that a cause-related marketing campaign that causes warm glow found to be a significant predictor of positive brand image. Thus, the following hypothesis can be made:

Hypothesis 1 (H1). Warm glow has a positive influence on overall image.

\subsubsection{The Effect of Self-Expressive Benefits on Overall Image}

The concept of self-expressive benefits has great significance for eco-friendly brands [76]. Customers who buy and use environmentally friendly products/services tend to show concern about the natural environment $[3,6]$, suggesting that satisfying environmental needs is a very important motivation in green consumption. Such green consumption helps to form self-image congruence with environmentally friendly products/services, which in turn creates good feelings toward a certain brand for customers [77-79]. In addition, consumers tend to prefer products that express their attitudes or values [80]. Thus, if customers can express their environmental concern with an environmentally friendly airline, they are more likely to feel a positive overall image of an environmentally friendly airline. Empirical studies also provide enough evidence to support the effect of self-expressive benefits on overall image. For example, Ahmad and Thyagaraj [38] found that if consumers perceive high levels of self-expressive benefits from a certain brand, they are more likely to have good feelings toward the brand. Integrating the theoretical and empirical backgrounds, the following hypothesis can be made:

Hypothesis 2 (H2). Self-expressive benefits have a positive influence on overall image.

\subsubsection{The Effect of Nature Experiences on Overall Image}

Environmental psychology shows that nature experiences help enhance positive emotional responses [81]. More importantly, positive emotional responses caused by nature experiences have a large effect on corporate image [82,83]. That is, consumers tend to have positive beliefs of product attributes when they perceive a high level of nature experiences [15]. Thus, if passengers feel close to nature when using an environmentally friendly airline, they will have a better image of the airline. Previous research also provides sufficient evidence to support the relationship between nature experiences and overall image. Bögeholz [50] argued that nature experiences play an important role in the formation of cognitive aspects (e.g. perception) and evaluative aspects (e.g. attitudes). In addition, Hartmann and Apaolaza-Ibáñez [15] also suggested that nature experiences are considered a key factor that promotes good feelings toward a brand. Based on the theoretical and empirical backgrounds, the following hypothesis was proposed:

Hypothesis 3 (H3). Nature experiences have a positive influence on overall image.

\subsubsection{The Effect of Overall Image on its Outcome Variables}

Overall image plays a crucial role in a consumer's decision-making process, so when consumers have a favorable image of a brand, they are more likely to show positive behavioral intentions $[84,85]$. Many empirical studies have also showed the important role of overall image in consumer behavior in diverse fields. For example, Han and Hyun [57] collected data from 286 passengers in order to find the role of overall image in the cruise industry and suggested that overall image has a positive impact on intentions to use. In addition, Durna, Dedeoglu and Balikçioglu [86] investigated how overall image influences word-of-mouth in the hotel industry. They analyzed data from 410 hotel customers and found that overall image is an important predictor of word-of-mouth. Lee et al. [85] proposed a theoretical model to investigate the importance of overall image in the green hotel industry using data from 416 hotel customers, suggesting that overall image plays a critical role in predicting willingness to pay more. Ko, Hwang and Kim [87] explored the importance of green marketing in the retail setting using 389 female customers at department stores. They found that product image formed by green marketing enhances purchase intention. Lastly, Yadav et al. [88] investigated the relationship 
between corporate image and intentions to visit a green hotel context using empirical data collected from 200 hotel customers. The data analysis indicated that corporate image is an important predictor of intention to visit. Based on theoretical and empirical backgrounds, the following hypotheses were therefore proposed:

Hypothesis 4 (H4). Overall image has a positive influence on intentions to use.

Hypothesis 5 (H5). Overall image has a positive influence on word-of-mouth intentions.

Hypothesis 6 (H6). Overall image has a positive influence on willingness to pay more.

\subsubsection{The Moderating Role of Gender}

Many studies in various fields have focused the moderating role of gender $[18,19,89]$, suggesting that gender is a social construct associated with all aspects of human behavior, so males and females have different behaviors. Social role theory provides theoretical background for gender differences. The theory suggested that "human beings behave in ways that are different and predictable depending on their respective social identities and the situation" [90], so males and females show different behaviors because of their different social roles [89,91].

The study of gender differences in consumption was extensively studied in eco-friendly research. For instance, Banerjee and McKeage [92] found that because females are more interested in green issues than males, they are trying to purchase environmentally friendly products. In addition, Laroche et al. [5] suggested that females are more concerned about the global environment than males, so they are more likely to pay more for eco-friendly products. Han et al. [18] also showed that if the hotel has an eco-friendly image, female customers are more likely to (1) stay at the hotel; (2) say positive things about the hotel to others; and (3) pay more for the hotel. Brough et al. [93] investigated the gender gap in sustainable consumption using 472 samples. They suggested that the green-feminine stereotype plays an important in the formation of sustainable consumption. López-Mosquera [94] tried to examine gender differences the willingness to pay for the conservation of the park using 200 samples and the data analysis result indicated that females have stronger the willingness to pay for the conservation of the park. More recently, Yang et al. [95] collected data from 1475 urban residents in order to identify the influence of personal demographic characteristics on green travel behavior. The results of data analysis showed that green travel behavior is more important to females than males. In other words, females are more sensitive to green travel behavior. Based on the above discussion, this study hypothesized the moderating role of gender in the relationship between overall image and its outcome variables including intentions to use, word-of-mouth intentions and willingness to pay more.

Hypothesis 4a (H4a). Overall image has a greater influence on intentions to use among females than among males.

Hypothesis 5a (H5a). Overall image has a greater influence on word-of-mouth intentions among females than among males.

Hypothesis 6a (H6a). Overall image has a greater influence on willingness to pay more among females than among males.

\subsection{Proposed Model}

This study proposes nine theoretical hypotheses based on the aforementioned theoretical background and integrates them into a conceptual model (see Figure 1). 


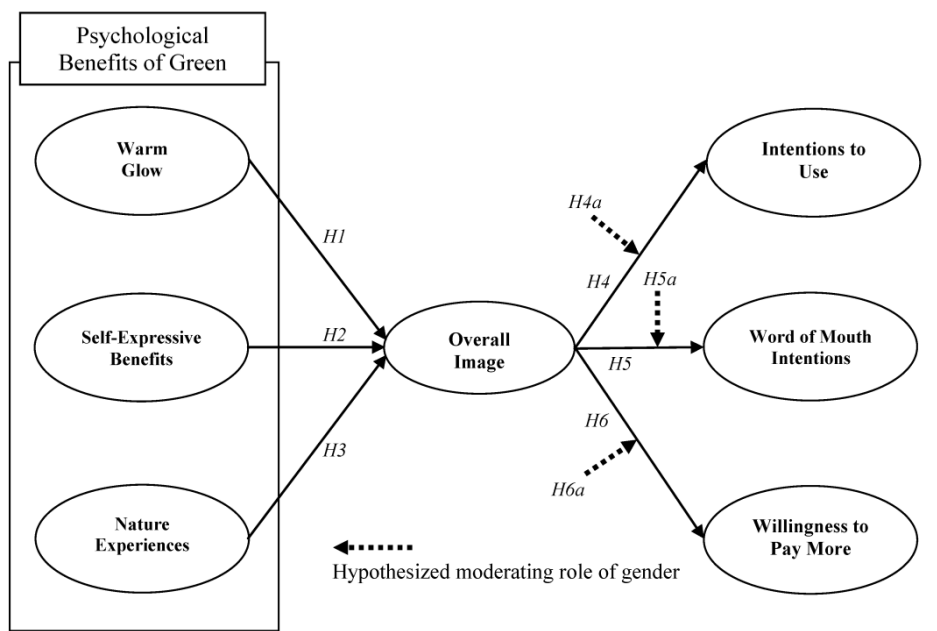

Figure 1. Proposed conceptual model.

\section{Methods}

\subsection{Measures and Questionnaire Development}

All of the variables were measured with multiple items that were adapted from the existing literature and modified to fit the airline industry. The psychological benefits of green brands consisted of three sub-dimensions (i.e. warm glow, self-expressive benefits and nature experiences) and were measured with nine items adapted from [15]. Overall image was measured based on the overall perceptions of an environmentally friendly airline using three items cited from $[59,61,96]$. Intentions to use were measured with three items employed by [42,44]. Word-of-mouth intentions were measured with three items developed by [97]. Willingness to pay more was measured with three items cited from $[18,98]$.

The questionnaire items were translated from English to Korean using a blind back-translation method. After that, the translated version of the questionnaire was carefully reviewed by three expert groups: (1) three faculty members whose main research focus was the airline industry; (2) five graduate students with relevant work experience; and (3) three employees currently working in the airline industry. The questionnaire used a seven-point Likert-type scale, anchored from strongly disagree (1) to strongly agree (7).

\subsection{Data Collection}

After the review by the three expert groups, the revised questionnaire was pre-tested with 30 actual airline passengers in Korea. Cronbach's alpha was employed to check the reliability of the measurement items. The results indicated that reliability was satisfactory, with Cronbach's $\alpha$ of all constructs over 0.70 [99]. The survey questionnaire was then distributed to airline passengers who had taken a flight up to six months prior to the survey. Since the context of this study was an environmentally friendly airline, participants were provided with a clear definition of the term 'environmentally friendly airline' below and the example of environmentally-friendly activities conducted by Asiana Airlines previously mentioned in the introduction.

"An environmentally friendly airline can be defined as an airline that tries to establish and implement business policies for global environmental protection (e.g. energy and water saving, reducing waste and recycling)."

The questionnaire was distributed to a total of 3735 panel members of an online survey company in Korea. Of these panel members, 341 answered the questionnaire. In order to check multivariate outliers, 
a visual inspection and Mahalanobis distance check were conducted, following which 19 outliers were deleted. Finally, 322 usable responses were used for further analysis.

\subsection{Sample Characteristics}

Table 1 shows the respondents' demographic profile. The gender ratio was the same. The average age was 39.31 years old. In terms of monthly income, $21.1 \%$ of the respondents indicated an income of between US\$2001 and US\$3000 and 20.8\% reported incomes of US\$3001 to US\$4000. With regard to marital status, $59.9 \%$ of respondents were married. Lastly, for education level, $60.2 \%$ of the respondents had completed undergraduate degrees.

Table 1. Profile of survey respondents $(n=322)$.

\begin{tabular}{llc}
\hline \multicolumn{1}{c}{ Variable } & $n$ & Percentage \\
\hline Gender & 161 & 50.0 \\
Male & 161 & 50.0 \\
Female & & \\
\hline Income & 27 & 8.4 \\
$\quad$ US\$6001 and over & 39 & 12.1 \\
US\$5001-US\$6000 & 47 & 14.6 \\
US\$4001-US\$5000 & 67 & 20.8 \\
US\$3001-US\$4000 & 68 & 21.1 \\
US\$2001-US\$3000 & 52 & 16.1 \\
US\$1001-US\$2000 & 22 & 6.8 \\
Under US\$1000 & & \\
\hline Marital status & 121 & 37.6 \\
Single & 193 & 59.9 \\
Married & 8 & 2.5 \\
Widowed/Divorced & & \\
\hline Education Level & 36 & 11.2 \\
Less than High school diploma & 54 & 16.8 \\
Associate's degree & 19 & 60.2 \\
Bachelor's degree & 38 & 11.8 \\
Graduate degree & & \\
\hline Mean Age = 39.31 years old & &
\end{tabular}

\section{Analysis and Results}

\subsection{Confirmatory Factor Analysis}

The measurement model was evaluated to check the appropriateness of the measurement structure. The results of the confirmatory factor analysis (CFA) showed that the model contained acceptable fit statistics $\left(\chi^{2}=453.358, d f=167, p<0.001\right.$, IFI $=0.962$, CFI $=0.962$, TLI $=0.952$, RMSEA $=0.073$ ). The factor loadings were equal to or greater than 0.806 and all factor loadings were significant at $p<0.001$.

Table 2 showed each construct and scale items with standardized loading. In addition, the composite reliabilities of constructs were greater than 0.70 , ranging from 0.882 to 0.964 , indicating that all constructs in the model have acceptable internal consistency [100]. All average variance extracted (AVE) estimates ranging from 0.713 to 0.900 were higher than 0.05 , which is the recommended threshold value [101], suggesting that convergent validity was supported. Lastly, as suggested by Fornell and Larcker [101], discriminant validity was evaluated by comparing the values of AVE with the squared correlation for each pair of constructs. The results revealed that the discriminant validity of study variables was evident in that the values of AVE were greater than the values of the squared correlations [see Table 3]. 
Table 2. Confirmatory factor analysis: Items and loadings.

\begin{tabular}{|c|c|}
\hline Construct and Scale Items & Standardized Loading ${ }^{a}$ \\
\hline \multicolumn{2}{|l|}{$\begin{array}{l}\text { Psychological benefits of green brands } \\
\text { Warm glow }\end{array}$} \\
\hline $\begin{array}{l}\text { With an environmentally friendly airline, I can feel good because they help to protect } \\
\text { the environment. }\end{array}$ & 0.851 \\
\hline $\begin{array}{l}\text { With an environmentally friendly airline, I have the feeling of contributing to the } \\
\text { well-being of humanity and nature. }\end{array}$ & 0.912 \\
\hline $\begin{array}{l}\text { With an environmentally friendly airline, I can feel better because they don't harm } \\
\text { the environment. }\end{array}$ & 0.933 \\
\hline \multicolumn{2}{|l|}{ Self-expressive benefits } \\
\hline With an environmentally friendly airline, I can express my environmental concern. & 0.843 \\
\hline $\begin{array}{l}\text { With an environmentally friendly airline, I can demonstrate to myself and my friends } \\
\text { that I care about environmental conservation. }\end{array}$ & 0.904 \\
\hline $\begin{array}{l}\text { With an environmentally friendly airline, my friends would perceive me to be } \\
\text { concerned about the environment. }\end{array}$ & 0.879 \\
\hline \multicolumn{2}{|l|}{ Nature experiences } \\
\hline An environmentally friendly airline can make me feel close to nature. & 0.871 \\
\hline $\begin{array}{l}\text { An environmentally friendly airline can make me think of nature, fields, } \\
\text { forests and mountains. }\end{array}$ & 0.919 \\
\hline An environmentally friendly airline can evoke the sensation of being in nature. & 0.899 \\
\hline \multicolumn{2}{|l|}{ Overall image } \\
\hline Overall image I have about an environmentally friendly airline is great. & 0.861 \\
\hline Overall image for taking an environmentally friendly airline is good. & 0.806 \\
\hline Overall, I have a good image about an environmentally friendly airline to take a trip. & 0.865 \\
\hline \multicolumn{2}{|l|}{ Intentions to use } \\
\hline I will take an environmentally friendly airline when traveling. & 0.873 \\
\hline I am willing to take an environmentally friendly airline when traveling. & 0.894 \\
\hline I will make an effort to take an environmentally friendly airline when traveling. & 0.915 \\
\hline \multicolumn{2}{|l|}{ Word-of-mouth intentions } \\
\hline I will say positive things about an environmentally friendly airline to others. & 0.914 \\
\hline I am willing to recommend an environmentally friendly airline to others. & 0.952 \\
\hline I will encourage others to take an environmentally friendly airline. & 0.932 \\
\hline \multicolumn{2}{|l|}{ Willingness to pay more } \\
\hline I am willing to pay more for an environmentally friendly airline. & 0.825 \\
\hline It is acceptable to pay more for an environmentally friendly airline. & 0.977 \\
\hline I am willing to spend extra in order to take an environmentally friendly airline. & 0.943 \\
\hline
\end{tabular}

a All factors loadings are significant at $p<0.001$.

Table 3. Descriptive statistics and associated measures.

\begin{tabular}{|c|c|c|c|c|c|c|c|c|c|c|}
\hline & No. of Items & Mean (S.D) & AVE & (1) & (2) & (3) & (4) & (5) & (6) & (7) \\
\hline (1) Warm glow & 3 & $5.70(0.95)$ & 0.809 & $0.927^{\mathrm{a}}$ & $0.593^{b}$ & 0.743 & 0.738 & 0.765 & 0.735 & 0.315 \\
\hline (2) Self-expressive benefits & 3 & $4.81(1.13)$ & 0.767 & $0.352^{c}$ & 0.908 & 0.788 & 0.698 & 0.616 & 0.632 & 0.528 \\
\hline (3) Nature experiences & 3 & $5.01(1.15)$ & 0.804 & 0.552 & 0.621 & 0.925 & 0.771 & 0.752 & 0.778 & 0.548 \\
\hline (5) Intentions to use & 3 & $5.34(1.00)$ & 0.800 & 0.585 & 0.379 & 0.566 & 0.699 & 0.923 & 0.785 & 0.531 \\
\hline (6) Word-of-mouth intentions & 3 & $5.19(1.12)$ & 0.870 & 0.540 & 0.399 & 0.605 & 0.661 & 0.616 & 0.953 & 0.456 \\
\hline (7) Willingness to pay more & 3 & $3.84(1.31)$ & 0.900 & 0.099 & 0.279 & 0.300 & 0.157 & 0.282 & 0.208 & 0.964 \\
\hline
\end{tabular}

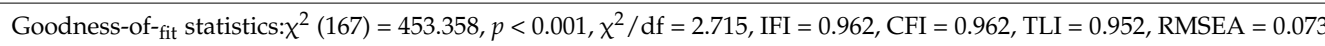

Note: AVE = average variance extracted; IFI = incremental fit index; CFI = comparative fit index; TLI = Tucker-Lewis index; RMSEA = root mean square error of approximation; ${ }^{a}$ composite reliabilities are along the diagonal; ${ }^{\mathrm{b}}$ correlations are above the diagonal; ${ }^{\mathrm{c}}$ squared correlations are below the diagonal. 


\subsection{Structural Equation Modeling}

The structural model was evaluated to validate the proposed associations among study constructs. The result of the structural equation modeling (SEM) indicated an acceptable fit of the model, demonstrating the soundness of our conceptual model and providing a good basis for testing the proposed links $\left(x^{2}=601.687, d f=179, p<0.001\right.$, IFI $=0.944$, CFI $=0.943$, TLI $=0.934$, RMSEA $=0.075)$. Figure 2 shows the SEM results with standardized coefficients. Of the six proposed hypotheses, all were statistically supported at $p<0.05$. Table 4 provides a summary of the hypotheses testing results.

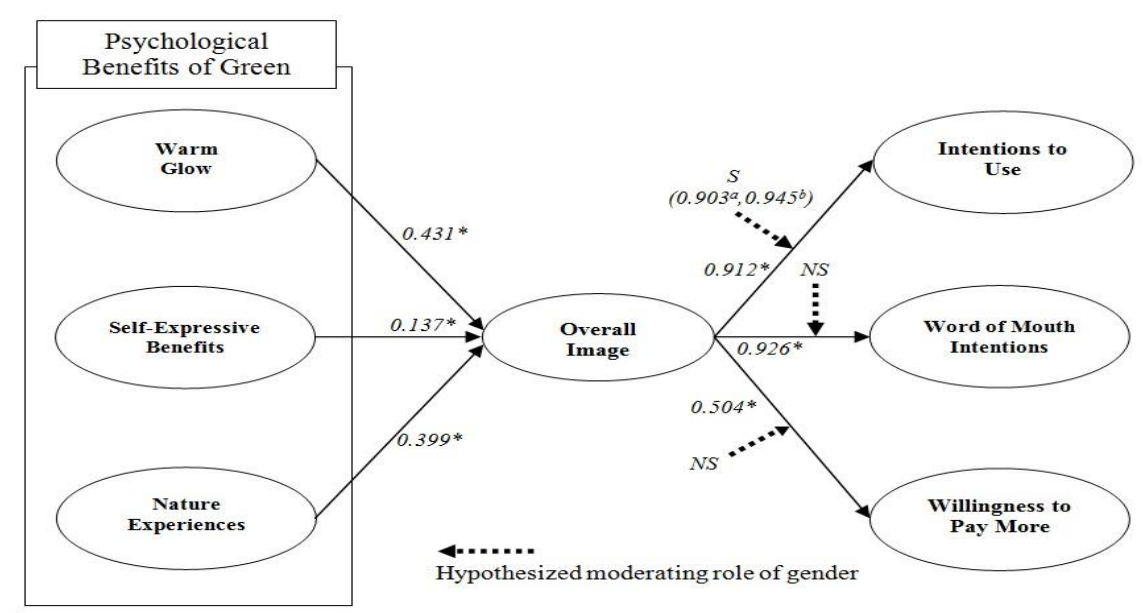

$* p<.05$

Notes $1: \mathrm{S}=$ significant, $\mathrm{NS}=$ not significant

Notes 2: a. path coefficient for male customers, b. path coefficient for female customers

Figure 2. Standardized theoretical path coefficients.

Table 4. Standardized parameter estimates for structural model.

\begin{tabular}{llcccc}
\hline & & & Standardized Estimate & $t$-Value & Hypothesis \\
\hline H1 Warm glow & $\rightarrow$ & Overall image & 0.431 & 6.898 & Supported \\
H2 Self-expressive benefits & $\rightarrow$ & Overall image & 0.137 & 2.168 & Supported \\
H3 Nature experiences & $\rightarrow$ & Overall image & 0.399 & 5.359 & Supported \\
H4 Overall image & $\rightarrow$ & Intentions to use & 0.912 & 16.191 & Supported \\
H5 Overall image & $\rightarrow$ & Word-of-mouth intentions & 0.926 & 16.821 & Supported \\
H6 Overall image & $\rightarrow$ & Willingness to pay more & 0.504 & 8.772 & Supported \\
\hline H4a The moderating role of gender in the relationship between overall image and intentions to use & Supported \\
\hline H5a The moderating role of gender in the relationship between overall image and word-of-mouth intentions & Not supported \\
\hline H6a The moderating role of gender in the relationship between overall image and willingness to pay more & Not supported \\
\hline \multicolumn{2}{l}{ Goodness-of-fit statistics: } \\
RMSEA = $\chi^{2}(179)=601.687, \chi^{2} / \mathrm{df}=3.361, p<0.001$, IFI $=0.944$, CFI $=0.943$, TLI $=0.934$,
\end{tabular}

\subsection{The Moderating Role of Gender}

Multiple-group analyses were conducted in order to test the moderating role of gender. Respondents $(n=322)$ were separated by gender: male $(n=161)$ and female $(n=161)$. The chi-square $\left(\chi^{2}\right)$ difference between the constrained and unconstrained models was examined with regard to the difference in degrees of freedom in order to check the differential effects of gender between male and female [102]. The results showed that the moderating role of gender in the relationship between overall image and intentions to use was supported $(\mathrm{H} 4 \mathrm{a})\left(\chi^{2}=4.653>\chi^{2}=0.5(1)=3.84, d f=1\right)$. However, other hypotheses were not significant at the 0.05 level as follows: H5a $\left(\chi^{2}=2.404<\chi^{2}=0.05(1)=3.84\right.$, $d f=1)$ and H6a $\left(\chi^{2}=2.038<\chi^{2}=0.05(1)=3.84, d f=1\right)$. 


\section{Discussion and Implications}

The purpose of this study was to investigate the important role of psychological benefits of green brands in an environmentally friendly airline context. More specifically, based on the literature review, it was proposed that three sub-dimensions of psychological benefits of green brands (i.e. warm glow, self-expressive benefits and nature experiences) positively affect overall image. In addition, a review of the existing literature suggested that overall image has a positive influence on three outcome variables-intentions to use, word-of-mouth intentions and willingness to pay more. Lastly, this study proposed that gender moderates the relationship between overall image and its outcome variables. Integrating the proposed theoretical relationships, a conceptual model was developed and tested using empirical data collected from 322 airline passengers. The hypotheses testing results have the following key theoretical and managerial implications.

\subsection{Theoretical Implications}

First, the data analysis revealed that warm glow positively influences overall image (0.431, $p<0.05)$. This result can be interpreted as showing that when passengers have a feeling of contributing to the protection of nature through the use of an environmentally friendly airline, they are more likely to perceive an overall favorable image about an environmentally friendly airline. Previous studies have also showed the importance of warm glow in diverse industries, suggesting that warm glow can play an important role in creating good feelings toward a brand [15]. In this regard, this study confirmed and further extended the existing theoretical relationship by finding the effect of warm glow on overall image in an environmentally friendly airline context for the first time.

Second, data analysis indicated that self-expressive benefits bear a significant impact on overall image $(0.137, p<0.05)$. This result emphasized the importance of self-image congruence which has been widely studied by previous scholars in many different fields $[78,103,104]$. They argued that people tend to select products/services congruent with their self-image. This study also supported the result of previous studies, suggesting that passengers are willing to use an environmentally friendly airline which is congruent with their self-image of being engaged with the protection of the environment. By doing so, they are more likely to feel that the overall image for an environmentally friendly airline is positive.

Third, nature experiences were found to have a significant impact on overall image $(0.399, p<0.05)$. This finding is consistent with Hartmann and Apaolaza-Ibáñez [15] and Kaplan [83], who suggest that nature experiences aid customers in developing a good feeling toward a brand. The result of this study also showed that when an environmentally friendly airline can make customers feel close to nature, passengers are more likely to have a good image about an environmentally friendly airline to take a trip. In this respect, this study replicated and expanded the existing literature by determining the significant role of nature experiences in the formation of overall image in an environmentally friendly airline context.

Another crucial contribution of this study is to show the role of overall image in an environmentally friendly airline context. Our study results showed that overall image positively affects the three outcome variables; intentions to use $(0.912, p<0.05)$, word-of-mouth intentions $(0.926, p<0.05)$ and willingness to pay more $(0.504, p<0.05)$. As a first attempt to identify the effect of overall image on intentions to use, word-of-mouth intentions and willingness to pay more in an environmentally friendly airline context, the results are consistent with previous studies $[57,85,86]$. That is, when passengers have a positive overall image about an environmentally friendly airline, they are more likely to (1) take an environmentally friendly airline when traveling; (2) recommend an environmentally friendly airline to others; and (3) spend extra in order to take an environmentally friendly airline.

Lastly, the data analysis result revealed that gender moderates the relationship between overall image and intentions to use. It can be interpreted that when female customers feel that overall image for taking an environmentally friendly airline is good, they are more likely to take an environmentally 
friendly airline when traveling. The finding is consistent with previous studies about gender differences in eco-friendly research $[5,18]$. However, contrary to expectation, hypothesis $5 \mathrm{a}$ and 6a were not supported. These results are somewhat different from those of other studies [18,93-95], which suggested that females are more sensitive to green behavior. This study showed that there is no gender gap in the relationship between (1) overall image and word-of-mouth intentions and (2) overall image and willingness to pay more in an environmentally friendly airline context. Therefore, in order to enhance word-of-mouth intentions and willingness to pay more, airlines do not need to consider gender differences when advertising.

\subsection{Managerial Implications}

The findings also have practical implications. First, the results showed that it is very important to give passengers the feeling that the airline has contributed to the protection of the environment because satisfying environmental needs is a key factor affecting green consumption $[3,6]$. Therefore, it is necessary to emphasize an airline's green image. In fact, many airlines have made more of an effort to show their green image through environmental management. For instance, United Airlines tried to practice 'Eco-Skies sustainability commitment' which helps to reduce year-over-year fuel consumption through fuel efficiency and operational improvements and to expand conversion from fossil fuel to electric ground service equipment [105]. In addition, Alaska Airlines showed a 79 percent recycle rate as flight attendants made significant effort to collect onboard recyclable materials such as paper, cups, bottles, cans and plastic [106]. Such environmental management can make their customers feel that using the airline helps to protect the environment which leads a positive overall image.

Second, the data analysis showed the important role of green advertising in the airline industry because if passengers can evoke the sensation of being in nature when they are exposed to an airline brand, they are more likely to have a positive overall image about that airline. Many previous studies have also stressed the importance of green advertising [107-110], suggesting that utilizing the natural environment in advertising makes customers feel close to nature which in turn stimulates consumption. Thus, if airline managers develop and use effective advertisements focusing on natural environment such as fields, forests and mountains, passengers are more likely to have a good image about the airline.

Third, the result of data analysis showed that gender plays the important moderating role in the relationship between overall image and intentions to use. Given the fact that the overall image of an environmentally friendly airline is more attractive to female customers, a customer segmentation strategy based on gender is needed. For this, it is required to create advertisements that emphasize a corporate green image and then if airline managers focus more on female customers when advertising (e.g. sales letters and promotion materials), they can maximize marketing effectiveness. By doing so, female customers are more likely to feel that overall image for taking an environmentally friendly airline is good. Consequently, they have high levels of intentions to take an environmentally friendly airline when traveling.

\section{Limitations and Future Research}

In spite of its contributions to the airline industry, this study has the following limitations. The data used in this study was collected from airline passengers in Korea, so the extent to which the results are cross-culturally generalizable can be limited. It is recommended that future research needs to test the proposed model with a different sample set in other countries or cultures. In addition, although the convenient sampling technique of using an online survey is widely used in consumer research, it can cause selection biases. Therefore, future study is necessary to decrease response bias through the use of different data collection methods. Lastly, although the conceptual hypotheses in this study were proposed based on the existing theoretical backgrounds in other green industries such as in the green hotel and green energy industry, it is important and meaningful to apply the existing hypothesis to other fields [111]. Therefore, hypotheses (the relationships between constructs) tested in this study would have greater external validity. 
Acknowledgments: This work was supported by Dongseo University, "Dongseo Frontier Project" Research Fund of 2014 .

Author Contributions: As the first author, Jinsoo Hwang contributed to the development of research model, data collection, and also the completion of the methodology, and result sections of this study. As the second (corresponding) author, Jung Kyu Choi contributed to the completion of the introduction and literature review sections of this study.

Conflicts of Interest: The authors declare no conflict of interest.

\section{References}

1. Jones, P.; Hillier, D.; Comfort, D. Sustainability in the hospitality industry: Some personal reflections on corporate challenges and research agendas. Int. J. Contemp. Hosp. Manag. 2016, 28, 36-67. [CrossRef]

2. Liu, X.; Yang, J.; Qu, S.; Wang, L.; Shishime, T.; Bao, C. Sustainable production: Practices and determinant factors of green supply chain management of Chinese companies. Bus. Strateg. Environ. 2012, 21, 1-16. [CrossRef]

3. Chan, E. Gap analysis of green hotel marketing. Int. J. Contemp. Hosp. Manag. 2013, 25, 1017-1048. [CrossRef]

4. Cheah, I.; Phau, I. Attitudes towards environmentally friendly products: The influence of ecoliteracy, interpersonal influence and value orientation. Mark. Intel. Plan. 2011, 29, 452-472. [CrossRef]

5. Laroche, M.; Bergeron, J.; Barbaro-Forleo, G. Targeting consumers who are willing to pay more for environmentally friendly products. J. Consum. Mark. 2001, 18, 503-520. [CrossRef]

6. Dubihlela, J.; Ngxukumeshe, T. Eco-friendly retail product attributes, customer attributes and the repurchase intentions of South African consumers. Int. Bus. Econ. Res. J. 2016, 15, 163-173. [CrossRef]

7. Kang, S.; Hur, W.M. Investigating the antecedents of green brand equity: A sustainable development perspective. Corp. Soc. Responsib. Environ. Manag. 2012, 19, 306-316. [CrossRef]

8. Dangelico, R.M.; Vocalelli, D. "Green Marketing": An analysis of definitions, strategy steps, and tools through a systematic review of the literature. J. Clean. Prod. 2017, 165, 1263-1279. [CrossRef]

9. Mokha, A.K. Green marketing: A study of consumer perception on using eco-friendly products. Asian J. Res. Bus. Econ. Manag. 2017, 7, 298-309. [CrossRef]

10. Asiana Airlines. Sustainability Report 2015. Available online: https://kr.flyasiana.com/C/pdf/ Sustainability_2015_eng.pdf (accessed on 31 July 2017).

11. Chen, Y.S. The drivers of green brand equity: Green brand image, green satisfaction, and green trust. J. Bus. Ethics 2010, 93, 307-319. [CrossRef]

12. Hagmann, C.; Semeijn, J.; Vellenga, D.B. Exploring the green image of airlines: Passenger perceptions and airline choice. J. Air. Transp. Manag. 2015, 43, 37-45. [CrossRef]

13. Hartmann, P.; Apaolaza-lbáñez, V. Virtual nature experiences as emotional benefits in green product consumption: The moderating role of environmental attitudes. Environ. Behav. 2008, 40, 818-842. [CrossRef]

14. Hartmann, P.; Apaolaza-Ibáñez, V. Green advertising revisited: Conditioning virtual nature experiences. Int. J. Advert. 2009, 28, 715-739. [CrossRef]

15. Hartmann, P.; Apaolaza-Ibáñez, V. Consumer attitude and purchase intention toward green energy brands: The roles of psychological benefits and environmental concern. J. Bus. Res. 2012, 65, 1254-1263. [CrossRef]

16. Sweeney, J.C.; Webb, D.A. How functional, psychological, and social relationship benefits influence individual and firm commitment to the relationship. J. Bus. Ind. Mark. 2007, 22, 474-488. [CrossRef]

17. Gwinner, K.P.; Gremler, D.D.; Bitner, M.J. Relational benefits in services industries: The customer's perspective. J. Acad. Mark. Sci. 1998, 26, 101-114. [CrossRef]

18. Han, H.; Hsu, L.T.J.; Lee, J.S. Empirical investigation of the roles of attitudes toward green behaviors, overall image, gender, and age in hotel customers' eco-friendly decision-making process. Int. J. Hosp. Manag. 2009, 28, 519-528. [CrossRef]

19. Kolyesnikova, N.; Dodd, T.H.; Wilcox, J.B. Gender as a moderator of reciprocal consumer behavior. J. Consum. Mark. 2009, 26, 200-213. [CrossRef]

20. Hartmann, P.; Apaolaza Ibáñez, V. Effects of green brand communication on brand associations and attitude. In International Advertising and Communication; DVU: Frankfurt, Germany, 2006; pp. 217-236.

21. Hartmann, P.; Apaolaza Ibáñez, V. Green value added. Mark. Intel. Plan. 2006, 24, 673-680. [CrossRef] 
22. Lin, C.H.; Morais, D.B.; Kerstetter, D.L.; Hou, J.S. Examining the role of cognitive and affective image in predicting choice across natural, developed, and theme-park destinations. J. Travel Res. 2007, 46, $183-194$. [CrossRef]

23. Lin, J.; Lin, J.; Lobo, A.; Lobo, A.; Leckie, C.; Leckie, C. Green brand benefits and their influence on brand loyalty. Mark. Intel. Plan. 2017, 35, 425-440. [CrossRef]

24. Clark, C.F.; Kotchen, M.J.; Moore, M.R. Internal and external influences on pro-environmental behavior: Participation in a green electricity program. J. Environ. Psychol. 2003, 23, 237-246. [CrossRef]

25. Andreoni, J. Giving with impure altruism: Applications to charity and Ricardian equivalence. J. Polit. Econ. 1989, 97, 1447-1458. [CrossRef]

26. Kahneman, D.; Knetsch, J.L. Valuing public goods: The purchase of moral satisfaction. J. Environ. Econ. Manag. 1992, 22, 57-70. [CrossRef]

27. Menges, R.; Schroeder, C.; Traub, S. Altruism, warm glow and the willingness-to-donate for green electricity: An art factual field experiment. Environ. Resour. Econ. 2005, 31, 431-458. [CrossRef]

28. Nunes, P.A.; Schokkaert, E. Identifying the warm glow effect in contingent valuation. J. Environ. Econ. Manag. 2003, 45, 231-245. [CrossRef]

29. Andreoni, J. Impure altruism and donations to public goods: A theory of warm-glow giving. Econ. J. 1990, 100, 464-477. [CrossRef]

30. Allison, T.H.; McKenny, A.F.; Short, J.C. The effect of entrepreneurial rhetoric on microlending investment: An examination of the warm-glow effect. J. Bus. Ventur. 2013, 28, 690-707. [CrossRef]

31. De Young, R. Some psychological aspects of reduced consumption behaviour: The role of intrinsic satisfaction and competence motivation. Environ. Behav. 1996, 28, 358-409. [CrossRef]

32. Videras, J.R.; Owen, A.L. Public goods provision and well-being: Empirical evidence consistent with the warm glow theory. B.E. J. Econ. Anal. Policy. 2006, 5, 1-40.

33. Brekke, K.A.; Kverndokk, S.; Nyborg, K. An economic model of moral motivation. J. Public Econ. 2003, 87, 1967-1983. [CrossRef]

34. Habel, J.; Schons, L.M.; Alavi, S.; Wieseke, J. Warm glow or extra charge? The ambivalent effect of corporate social responsibility activities on customers' perceived price fairness. J. Mark. 2016, 80, 84-105. [CrossRef]

35. Aaker, J. The malleable self: The role of self-expression in persuasion. J. Mark. Res. 1999, 36, 45-47. [CrossRef]

36. Aaker, D.A. Building Strong Brands; Free Press: New York, NY, USA, 2002.

37. Glazer, A.; Konrad, K.A. A signaling explanation for charity. Am. Econ. Rev. 1996, 86, 1019-1028.

38. Hu, H.H.S. The effectiveness of environmental advertising in the hotel industry. Cornell. Hosp. Q. 2012, 3, 154-164. [CrossRef]

39. Sirgy, M.J. Self-Congruity: Toward a Theory of Personality and Cybernetics; Praeger Publishers/Greenwood Publishing Group: Santa Barbara, CA, USA, 1986.

40. Usakli, A.; Baloglu, S. Brand personality of tourist destinations: An application of self-congruity theory. Tour. Manag. 2011, 32, 114-127. [CrossRef]

41. Belz, F.; Dyllik, T. Ökologische Positionierungsstrategien. In Positionierung: Kernentscheidung des Market; Thexis: St. Gallen, Switzerland, 1996; pp. 170-179.

42. Bennett, A.; Chakravarti, A. The self and social signaling explanations for consumption of CSR-associated products. NA-Adv. Consum. Res. 2009, 36, 49-50.

43. Aaker, D. Beyond functional benefits. Mark. News. 2009, 9, 23.

44. Ahmad, A.; Thyagaraj, K.S. Consumer's intention to purchase green brands: The roles of environmental concern, environmental knowledge and self expressive benefits. Curr. World Environ. 2015, 10, 879-889. [CrossRef]

45. Curtin, S. Nature, wild animals and tourism: An experiential view. J. Ecotourism. 2005, 4, 1-15. [CrossRef]

46. Lee, W.H.; Moscardo, G. Understanding the impact of ecotourism resort experiences on tourists' environmental attitudes and behavioural intentions. J. Sustain. Tour. 2005, 13, 546-565. [CrossRef]

47. Leather, P.; Pyrgas, M.; Beale, D.; Lawrence, C. Windows in the workplace: Sunlight, view, and occupational stress. Environ. Behav. 1998, 30, 739-762. [CrossRef]

48. Maller, C.; Townsend, M.; Pryor, A.; Brown, P.; St Leger, L. Healthy nature healthy people: Contact with nature as an upstream health promotion intervention for populations. Health. Promot. Int. 2006, 21, 45-54. [CrossRef] [PubMed] 
49. Kuo, F.E.; Sullivan, W.C. Aggression and violence in the inner city: Effects of environment via mental fatigue. Environ. Behav. 2001, 33, 543-571. [CrossRef]

50. Bögeholz, S. Nature experience and its importance for environmental knowledge, values and action: Recent German empirical contributions. Environ. Educ. Res. 2006, 12, 65-84. [CrossRef]

51. Finger, M. From knowledge to action? Exploring the relationships between environmental experiences, learning and behavior. J. Soc. Issues 1994, 50, 141-160. [CrossRef]

52. Mayer, F.S.; Frantz, C.M.; Bruehlman-Senecal, E.; Dolliver, K. Why is nature beneficial? The role of connectedness to nature. Environ. Behav. 2009, 41, 607-643. [CrossRef]

53. Andereck, K.L.; Nyaupane, G.P. Exploring the nature of tourism and quality of life perceptions among residents. J. Travel Res. 2011, 50, 248-260. [CrossRef]

54. Crompton, J.L. An assessment of the image of Mexico as a vacation destination and the influence of geographical location upon that image. J. Travel Res. 1979, 17, 18-23. [CrossRef]

55. Gartner, W.C. Temporal influences on image change. Ann. Tour. Res. 1986, 13, 635-644. [CrossRef]

56. Bloemer, J.; De Ruyter, K. On the relationship between store image, store satisfaction and store loyalty. Eur. J. Mark. 1998, 32, 499-513. [CrossRef]

57. Han, H.; Hyun, S.S. Impact of hotel-restaurant image and quality of physical-environment, service, and food on satisfaction and intention. Int. J. Hosp. Manag. 2017, 63, 82-92. [CrossRef]

58. Baloglu, S.; Brinberg, D. Affective images of tourism destinations. J. Travel Res. 1997, 35, 11-15. [CrossRef]

59. Zeithaml, V.A.; Berry, L.L.; Parasuraman, A. The behavioral consequences of service quality. J. Mark. 1996, 60, 31-46. [CrossRef]

60. Colgate, M.; Lang, B. Switching barriers in consumer markets: An investigation of the financial services industry. J. Consum. Mark. 2001, 18, 332-347. [CrossRef]

61. Han, H.; Yoon, H.J. Hotel customers' environmentally responsible behavioral intention: Impact of key constructs on decision in green consumerism. Int. J. Hosp. Manag. 2015, 45, 22-33. [CrossRef]

62. Jeong, M.; Lambert, C.U. Adaptation of an information quality framework to measure customers' behavioral intentions to use lodging Web sites. Int. J. Hosp. Manag. 2001, 20, 129-146. [CrossRef]

63. Nysveen, H.; Pedersen, P.E.; Thorbjørnsen, H.; Berthon, P. Mobilizing the brand the effects of mobile services on brand relationships and main channel use. J. Serv. Res. 2005, 7, 257-276. [CrossRef]

64. Westbrook, R.A. Product/consumption-based affective responses and postpurchase processes. J. Mark. Res. 1987, 24, 258-270. [CrossRef]

65. Söderlund, M. Customer satisfaction and its consequences on customer behaviour revisited: The impact of different levels of satisfaction on word-of-mouth, feedback to the supplier and loyalty. Int. J. Serv. Ind. Manag. 1998, 9, 169-188. [CrossRef]

66. Groth, M. Customers as good soldiers: Examining citizenship behaviors in internet service deliveries. J. Manag. 2005, 31, 7-27. [CrossRef]

67. Yi, Y.; Gong, T. The effects of customer justice perception and affect on customer citizenship behavior and customer dysfunctional behavior. Ind. Mark. Manag. 2008, 37, 767-783. [CrossRef]

68. Cameron, T.A.; James, M.D. Estimating willingness to pay from survey data: An alternative pre-test-market evaluation procedure. J. Mark. Res. 1987, 24, 389-395. [CrossRef]

69. Netemeyer, R.G.; Krishnan, B.; Pullig, C.; Wang, G.; Yagci, M.; Dean, D.; Wirth, F. Developing and validating measures of facets of customer-based brand equity. J. Bus. Res. 2004, 57, 209-224. [CrossRef]

70. Han, H.; Hyun, S.S.; Kim, W. In-flight service performance and passenger loyalty: A cross-national (China/Korea) study of travelers using low-cost carriers. J. Travel Tour. Mark. 2014, 31, 589-609. [CrossRef]

71. Wieseke, J.; Alavi, S.; Habel, J. Willing to pay more, eager to pay less: The role of customer loyalty in price negotiations. J. Mark. 2014, 78, 17-37. [CrossRef]

72. Miao, L.; Mattila, A.S. How and how much to reveal? The effects of price transparency on consumers' price perceptions. J. Hosp. Tour. Res. 2007, 31, 530-545. [CrossRef]

73. Homburg, C.; Koschate, N.; Hoyer, W.D. Do satisfied customers really pay more? A study of the relationship between customer satisfaction and willingness to pay. J. Mark. 2005, 69, 84-96. [CrossRef]

74. Raje, D.V.; Dhobe, P.S.; Deshpande, A.W. Consumer's willingness to pay more for municipal supplied water: A case study. Ecol. Econ. 2002, 42, 391-400. [CrossRef]

75. Müller, S.S.; Fries, A.J.; Gedenk, K. How much to give?-The effect of donation size on tactical and strategic success in cause-related marketing. Int. J. Res. Mark. 2014, 31, 178-191. [CrossRef] 
76. Mannetti, L.; Pierro, A.; Livi, S. Recycling: Planned and self-expressive behaviour. J. Environ. Psychol. 2004, 24, 227-236. [CrossRef]

77. Claiborne, C.B.; Sirgy, M.J. Self-image congruence as a model of consumer attitude formation and behavior: A conceptual review and guide for future research. In Proceedings of the 1990 Academy of Marketing Science (AMS) Annual Conference; Springer: Cham, Switzerland, 2015; pp. 1-7.

78. Hosany, S.; Martin, D. Self-image congruence in consumer behavior. J. Bus. Res. 2012, 65, 685-691. [CrossRef]

79. Sirgy, M.J.; Su, C. Destination image, self-congruity, and travel behavior: Toward an integrative model. J. Travel Res. 2000, 38, 340-352. [CrossRef]

80. Orth, U. Different brands for different occasions-Drivers of consumer public and private choices. In Proceedings of the 3rd International Wine Business and Marketing Research Conference, Roussillon, France, 6-8 July 2006.

81. Ulrich, R.S. Natural versus urban scenes: Some psycho physiological effects. Environ. Behav. 1981, 13, 523-556. [CrossRef]

82. Hartig, T.; Mang, M.; Evans, G.W. Restorative effects of natural environment experiences. Environ. Behav. 1991, 23, 3-26. [CrossRef]

83. Kaplan, S. The restorative benefits of nature: Toward an integrative framework. J. Environ. Psychol. 1995, 15, 169-182. [CrossRef]

84. Kotler, P.; Gertner, D. Country as brand, product, and beyond: A place marketing and brand management perspective. J. Brand Manag. 2002, 9, 249-261. [CrossRef]

85. Lee, J.S.; Hsu, L.T.; Han, H.; Kim, Y. Understanding how consumers view green hotels: How a hotel's green image can influence behavioural intentions. J. Sustain. Tour. 2010, 18, 901-914. [CrossRef]

86. Durna, U.; Dedeoglu, B.B.; Balikçioglu, S. The role of servicescape and image perceptions of customers on behavioral intentions in the hotel industry. Int. J. Contemp. Hosp. Manag. 2015, 27, 1728-1748. [CrossRef]

87. Ko, E.; Hwang, Y.K.; Kim, E.Y. Green marketing functions in building corporate image in the retail setting. J. Bus. Res. 2013, 66, 1709-1715. [CrossRef]

88. Yadav, R.; Yadav, R.; Kumar Dokania, A.; Kumar Dokania, A.; Swaroop Pathak, G.; Swaroop Pathak, G. The influence of green marketing functions in building corporate image: Evidences from hospitality industry in a developing nation. Int. J. Contemp. Hosp. Manag. 2016, 28, 2178-2196. [CrossRef]

89. Archer, J. Sex differences in social behavior: Are the social role and evolutionary explanations compatible? Am. Psychol. 1996, 51, 909-917. [CrossRef] [PubMed]

90. Biddle, B.J. Recent developments in role theory. Annu. Rev. Sociol. 1986, 12, 67-92. [CrossRef]

91. Buss, D. The evolutionary psychology of human social strategies. In Social Psychology: Handbook of Basic Principles; Higgins, E.T., Kruglanski, A.W., Eds.; The Guilford Press: New York, NY, USA, 1996; pp. 3-38.

92. Banerjee, B.; McKeage, K. How green is my value: Exploring the relationship between environmentalism and materialism. ACR N. Am. Adv. 1994, 21, 147-152.

93. Brough, A.R.; Wilkie, J.E.; Ma, J.; Isaac, M.S.; Gal, D. Is eco-friendly unmanly? The green-feminine stereotype and its effect on sustainable consumption. J. Consum. Res. 2016, 43, 567-582. [CrossRef]

94. López-Mosquera, N. Gender differences, theory of planned behavior and willingness to pay. J. Environ. Psychol. 2016, 45, 165-175. [CrossRef]

95. Yang, R.; Long, R.; Bai, Y.; Li, L. The influence of household heterogeneity factors on the green travel behavior of urban residents in the East China region. Sustainability. 2017, 9, 237. [CrossRef]

96. Jani, D.; Han, H. Personality, satisfaction, image, ambience, and loyalty: Testing their relationships in the hotel industry. Int. J. Hosp. Manag. 2014, 37, 11-20. [CrossRef]

97. Gremler, D.D.; Gwinner, K.P. Customer-employee rapport in service relationships. J. Serv. Res. 2000, 3, 82-104. [CrossRef]

98. Ham, S.; Han, H. Role of perceived fit with hotels' green practices in the formation of customer loyalty: Impact of environmental concerns. Asia Pac. J. Tour. Res. 2014, 18, 731-748. [CrossRef]

99. Nunnally, J.C. Psychometric Theory; McGraw-Hill: New York, NY, USA, 1978.

100. Bagozzi, R.P.; Yi, Y. On the evaluation of structural equation models. J. Acad. Mark. Sci. 1988, 16, 74-94. [CrossRef]

101. Fornell, C.; Larcker, D.F. Evaluating structural equation models with unobservable variables and measurement error. J. Mark. Res. 1981, 18, 39-50. [CrossRef] 
102. Anderson, J.C.; Gerbing, D.W. Structural equation modeling in practice: A review and recommended two-step approach. Psychol. Bull. 1988, 103, 411-423. [CrossRef]

103. Kressmann, F.; Sirgy, M.J.; Herrmann, A.; Huber, F.; Huber, S.; Lee, D.J. Direct and indirect effects of self-image congruence on brand loyalty. J. Bus. Res. 2006, 59, 955-964. [CrossRef]

104. Sirgy, M.J.; Grewal, D.; Mangleburg, T.F.; Park, J.O.; Chon, K.S.; Claiborne, C.B.; Berkman, H. Assessing the predictive validity of two methods of measuring self-image congruence. J. Acad. Mark. Sci. 1997, 25, 229-241. [CrossRef]

105. United. Eco-Skies sustainability commitment. Available online: http://crreport.united.com/environment/ eco-skies-sustainability-commitment (accessed on 31 July 2017).

106. Alaska. Alaska Air Group. 2015 Sustainability Report. Available online: https://www.alaskaair.com/ content/about-us/sustainability-report/environment/inflight-waste.aspx (accessed on 31 July 2017).

107. Karna, J.; Juslin, H.; Ahonen, V.; Hansen, E. Green advertising: Greenwash or a true reflection of marketing strategies? Greener Manag. Int. 2001, Spring, 59-71. [CrossRef]

108. Muralidharan, S.; La Ferle, C.; Sung, Y. Are we a product of our environment? Assessing culturally congruent Green advertising appeals, novelty, and environmental concern in India and the USA. Asian J. Commun. 2017, 27, 1-9. [CrossRef]

109. Royne, M.B.; Martinez, J.; Oakley, J.; Fox, A.K. The effectiveness of benefit type and price endings in green advertising. J. Advert. 2012, 41, 85-102. [CrossRef]

110. Zinkhan, G.M.; Carlson, L. Green advertising and the reluctant consumer. J. Advert. 1995, 24, 1-6. [CrossRef]

111. Bacharach, S.B. Organizational theories: Some criteria for evaluation. Acad. Manag. Rev. 1989, 14, 496-515.

(C) 2017 by the authors. Licensee MDPI, Basel, Switzerland. This article is an open access article distributed under the terms and conditions of the Creative Commons Attribution (CC BY) license (http:/ / creativecommons.org/licenses/by/4.0/). 